\title{
PENGARUH PENDEKATAN CTL TERHADAP PEMAHAMAN \\ MATEMATIKA SISWA KELAS IV BERDASARKAN \\ JENIS KELAMIN DI SD NEGERI KOTA PADANG
}

\author{
Febria Wulandari1), Mardiah Harun 2), Firman 3) \\ Email:firman@konselor.org
}

\begin{abstract}
The problem of this research was the students had low understanding on Matematics. This problem was led by some factors. The factors were the low students involvement in a teaching-learning process, the unrelevant material to their daily life, and the less involvement to concept building during the learning process. The aims of this research were to explain: (1) the different Math understanding betwen the students taught by using CTL approach and conventional technique, in teaching Math for $4^{\text {th }}$ grade students of Elementary School in Padang, (2) the different Math understanding between male and female students of $4^{\text {th }}$ grade of elementary school in Padang, and (3) the different interaction between teaching approach and gender in influencing Math understanding of $4^{\text {th }}$ grade students of Elementary School in Padang.

This research was Quasi Experimental Design research by using factorial design. The population of this research was all of $4^{\text {th }}$ grade students of Elementary School in North Padang municipality. The sample gotten through random sampling were SDN 11 Lolong as the control class and SDN 13 Lolong as the experimental class, CTL was implemented; meanwhile, in the control class, conventional technique was implemented. Futhermore, the data of this research was collected through students' achievement sheet. Then the hypothesis was tested by using two ways anava.

From the result of this research, it can be concluded that (1) there was no different on Math understanding between students' taught by using CTL approach and those who were taught by using conventional technique, (2) there was no different on Math understanding between male and female students, and (3) there was no significant interaction between teaching approach and gender in influencing Math understanding.
\end{abstract}

Key Words: CTL approach, understanding of Mathematics, gender

\section{Pendahuluan}

Matematika merupakan ilmu universal yang mendasari perkembangan teknologi modern, mempunyai peranan penting dalam berbagai disiplin dan memajukan daya pikir manusia. Matematika salah satu mata pelajaran yang diajarkan pada setiap jenjang pendidikan mulai SD sampai dengan perguruan tinggi. 
Depdiknas, (2006:416), menjelaskan bahwa "Tujuan Matematika diajarkan di SD adalah untuk membekali peserta didik dengan kemampuan berfikir logis, analitis, sistematis, kritis, dan kreatif, serta kemampuan bekerjasama”. Kemampuan tersebut diperlukan agar peserta didik dapat memperoleh, mengelola, dan memanfaatkan informasi untuk bertahan hidup pada keadaan yang selalu berubah, tidak pasti, dan kompetitif.

Matematika merupakan mata pelajaran yang berperan sebagai pelajaran untuk matematika itu sendiri maupun ilmu lainnya. Penguasaan matematika harusnya diperoleh sejak dini. Dengan demikian, dapat menunjang keberhasilan siswa untuk menempuh pendidikan selanjutnya seperti ke perguruan tinggi.

Tujuan

pembelajaran

Matematika sesuai dengan

Permendiknas No.22 Tahun 2006

adalah melatih peserta didik untuk memahami konsep Matematika, mengembangkan kemampuan dalam menarik kesimpulan, menyelesaikan masalah dan mengkomunikasikan gagasan, serta menata cara berfikir dan pembentukan keterampilan sehingga mengubah tingkah laku peserta didik.
Selain itu, pembelajaran Matematika di Sekolah Dasar juga bertujuan agar peserta didik terampil dalam menggunakan berbagai konsep matematika dalam kehidupan seharihari. Contohnya dalam membagi satu buah kue untuk dua orang maka konsep yang digunakan adalah konsep matematika.

Berbagai upaya telah dilakukan dalam meningkatkan kualitas pembelajaran, terutama pelajaran matematika mulai dari perubahan kurikulum. Perubahan kurikulum dimaksudkan untuk menyesuaikan standar isi pelajaran dengan perkembangan ilmu pengetahuan dan teknologi. Kualitas pendidik juga diperbaiki mulai dari adanya KKG (Kelompok Kerja Guru). KKG merupakan wahana para guru untuk berdiskusi tentang masalah yang dihadapi di kelas serta memberikan inovasi baru dalam proses pembelajaran. Selain itu, pemerintah juga meningkatkan sarana dan prasarana pendidikan seperti menambah bukubuku pelajaran.

Kenyataan akan rendahnya hasil belajar Matematika yang diperoleh peserta didik, tidak terlepas dari bagaimana proses pembelajaran yang 
berlangsung selama ini. Salah satu faktor yang mempengaruhi keberhasilan proses pembelajaran adalah pendekatan yang digunakan dalam proses pembelajaran itu. Pendekatan belajar yang tepat akan memudahkan peserta didik dalam mencerna materi yang dipelajari. Dalam pembelajaran Matematika ada banyak kemungkinan pendekatan yang dapat digunakan seperti pendekatan konvensional dan pendekatan CTL.

\section{Pendekatan pembelajaran}

konvensional dipandang kurang efektif, karena proses pembelajarannya hanya berpusat pada guru dan peserta didik tidak diberi kesempatan untuk aktif mengembangkan pengetahuannya. Pembelajaran Matematika berbeda dengan pelajaran lain bahkan kebanyakan peserta didik menganggap pelajaran matematika adalah pelajaran yang sulit. Sehingga dapat dilihathasil belajar peserta didik pada pelajaran Matematika rendah. Dalam mempelajari matematika tidak cukup hanya dengan menghafal, tetapi juga diperlukan pemahaman, ketelitian dan latihan secara terus-menerus. Dengan kata lain mempelajari matematika perlu keaktifan peserta didik. Wallace (1992) menjelaskan pendekatan konvensional memandang bahwa proses pembelajaran yang dilakukan sebagaimana umumnya guru mengajarkan materi kepada siswanya. Guru menjadi peran utama dalam proses pembelajaran.

$$
\text { Penggunaan pendekatan }
$$
pembelajaran yang monoton akan membuat perhatian peserta didik kurang karena proses pembelajaran membosankan. Heruman (2012) menjelaskan bahwa untuk mengembangkan kreativitas dan kompetensi peserta didik, maka guru hendaknya dapat menyajikan pembelajaran yang efektif dan efisien, sesuai dengan kurikulum dan pola pikir peserta didik. Pendekatan pembelajaran diharapkan dapat mengubah gaya belajar yang pasif menjadi aktif dalam mengkontruksi konsep. Pendekatan pembelajaran yang tepat dapat membuat pembelajaran Matematika lebih berarti dan menyenangkan bagi peserta didik.

$$
\text { Pendekatan }
$$

Contextual

Teaching and Learning (CTL) jika dibandingkan dengan pendekatan konvensional lebih banyak keunggulan. Pendekatan Kontekstual (contextual) merupakan salah satu pendekatan belajar yang mampu menghidupkan kelas agar peserta didik belajar dengan sesungguhnya. Taufik dan Muhammadi, 
(2012:189) menjelaskan bahwa "Pendekatan Kontekstual merupakan suatu model pembelajaran dimana guru menghadirkan situsasi dunia nyata ke dalam kelas dan mendorong peserta didik membuat hubungan antara pengetahuan yang dimilikinya dengan penerapannya dalam kehidupan mereka". Jadi pendekatan kontekstual dapat mengaitkan pengetahuan yang dimiliki oleh peserta didik dengan situasi dunia nyata.

Keberhasilan suatu proses pembelajaran tidak hanya ditentukan oleh pemilihan dan penggunaan metode atau pendekatan pembelajaran saja. Akan tetapi ada banyak faktor yang mempengaruhinya, diantaranya adalah perbedaan jenis kelaminantar peserta didik. Dilihat dari perbedaan jenis kelamin antara laki-laki dan perempuan juga mempengaruhi gaya belajar peserta didik dalam menyelesaikan matematika. Peserta didik laki-laki lebih aktif dalam belajar dibandingkan peserta didik perempuan. Penelitianyang dilakukan Rushton (2006), menjelaskan bahwa perbedaan prestasi belajar laki-laki dan perempuan lebih disebabkan oleh perbedaan tingkat intelegensi.

$$
\text { Geary (2000) pada }
$$

penelitiaanya juga menjelaskan bahwa laki-laki lebih aktif dari perempuan. Gearymenyatakan bahwa pengaruh faktor jenis kelamin dalam matematika adalah karena adanya perbedaan biologis dalam otak anak laki-laki dan perempuan yang diperoleh melalui hasil observasi, dimana anak perempuan secara umum lebih unggul dalam bidang bahasa dan menulis, sedangkan anak laki-laki lebih unggul dalam bidang matematika karena kemampuankemampuan ruang anak laki-laki lebih baik.

Nafi'an menjelaskan perbedaan laki-laki dan perempuan dalam belajar matematika adalah laki-laki lebih unggul dalam penalaran, sedangkan perempuan lebih unggul dalam ketepatan, ketelitian, kecermatan, dan keseksamaan berpikir. Laki-laki memiliki pemahaman matematika dan mekanika yang lebih baik dari pada perempuan, perbedaan ini tidak nyata pada tingkat sekolah dasar akan tetapi menjadi tampak lebih jelas pada tingkat yang lebih tinggi.

Berdasarkan fenomena tersebut apakah dapat dikatakan bahwa apakah terdapat keterkaitan antara pendekatan pembelajaran yang digunakan dengan perbedaan jenis kelamin peserta didik dalam proses pembelajaran Matematika. 
Oleh karena itu, maka akan dilakukan penelitian dengan judul "Pengaruh Pendekatan CTL Terhadap Pemahaman Matematika Siswa Kelas IV Berdasarkan Jenis Kelamin di SD Negeri Kota Padang ”.

\section{Metodologi Penelitian}

Berdasarkan permasalahan dan tujuan yang ingin dicapai, maka penelitian ini menggunakan pendekatan kuantitatif dalam bentuk Quasi Eksprimental Design. Sesuai dengan desain penelitian maka penelitian menggunakan dua kelas yaitu kelas eksperimen dan kelas kontrol.Kelas eksperimen adalah kelas yang diberi perlakuan Pendekatan CTL, sedangkan kelas kontrol menggunakan pendekatan konvensional.

Variabel dalam penelitian ini terdiri dari (1) variabel bebas yaitu Pendekatan pembelajaran, (2) variabel terikat yaitu hasil belajar, dan (3) variabel moderator yaitu jenis kelamin.

Penelitian ini dilaksanakan di SDN Kecamatan Padang Utara Kota Padang. Dari 9 sekolah yang ada pada Kecamatan Padang Utara, dipilih dua kelas secara acak untuk dijadikan sebagai kelas eksperimen dan kelas kontrol. Penelitian untuk Kelas eksperimen dilaksanakan di SDN 13
Lolong sedangkan penelitian kelas kontrol dilaksanakan di SDN 11 Lolong. Untuk uji coba tes hasil belajar dilakukan di SDN 20 Berok. Waktu penelitian dilaksanakan pada semester genap TA 2015/2016. Penelitian ini dimulai pada tanggal 18 April sampai 7 Mei 2016.

Populasi pada penelitian ini adalah seluruh peserta didik kelas IV SDN Kecamatan Padang Utara Kota Padang yang terdaftar pada semester genap TA 2015/2016 yang terdiri dari 9 sekolah.

Teknik yang digunakan dalam penarikan sampel adalah Random Sampling. Teknik ini digunakan karena populasi mempunyai anggota/unsur yang homogen secara proporsional. Berdasarkan populasi yang ada, untuk memilih sampelnya dilakukan uji normalitas, uji homogenitas, dan uji kesamaan rata-rata. Sampel adalah sebagian dari populasi yang memiliki sifat dan karakter yang sama sehingga betul-betul mewakili populasinya. Trianto (2009:256) menjelaskan bahwa "Sampel adalah sebagian atau wakil populasi yang diteliti”.

Pengambilan sampel dilakukan dengan teknik random sampling, yaitudipilih secara acak. Pengambilan 
sampel dilakukan dengan cara Lot. Dari pengundian terpilih SDN 13 Lolong sebagai kelas eksperimen dan SDN 11 Lolong sebagai kelas kontrol.

Variabel merupakan sesuatu yang menjadi objek penelitian, menurut Yusuf (2013:101) "Variabel pada hakikatnya merupakan konsep yang mempunyai variasi nilai". Dalam penelitian ini terdapat tiga variabel dengan uraian sebagai berikut:

a. Variabel bebas

Variabel bebas pada penelitian ini adalah Pendekatan CTL dan pendekatan konvensional.

b. Variabel terikat

Variabel terikat pada penelitian ini adalah hasil belajar pada tingkatan C2 (Pemahaman/ Undestanding),

c. Variabel moderator

Variabel moderator pada penelitian adalah jenis kelamin

Jenis data yang diperlukan dalam penelitian ini adalah jenis data kuantitatif. Sumber data dalam penelitian ini adalah sumber data primer dan sumber data sekunder, yaitu:

1) Data primer yaitu data yang langsung diambil dari hasil tes belajar peserta didik sebelum dan sesudah diajar menggunakan Pendekatan CTL dan data tes akhir belajar pada kelas IV SD N Kota Padang.

2) Data sekunder yaitu data yang diperoleh dari pihak-pihak tertentu, seperti data peserta didik dan nilai UH I pada pembelajaran Matematika di kelas IV SD N Kota Padang.

Untuk mengumpulkan data-data hasil penelitian dilakukan tiga tahap yaitu tahap persiapan, tahap pelaksanaan, dan tahap penilaian.

Rancangan atau desain eksperimen yang akan digunakan pada penelitian ini adalah factorial design, yaitu dengan memperhatikan adanya variabel moderator yang mempengaruhi perlakuan variabel independen terhadap hasil variabel dependen (desain faktorial 2 x 2), (Yusuf, 2013:191). Rancangan atau desain penelitian ini dapat digambarkan seperti tabel 10 berikut:

Tabel. Rancangan Penelitian Factorial Design

\begin{tabular}{|c|c|c|c|}
\hline & \multicolumn{2}{|c|}{ Pendekatan } \\
\hline & & $\operatorname{CTL}\left(\mathrm{A}_{1}\right)$ & $\begin{array}{c}\text { Konvensional } \\
\left(\mathrm{A}_{2}\right)\end{array}$ \\
\hline \multirow{3}{*}{$\begin{array}{c}\text { Jenis } \\
\text { Kelamin }\end{array}$} & $\begin{array}{l}\text { Laki-laki } \\
\left(\mathrm{B}_{1}\right)\end{array}$ & $\begin{array}{ll}\left(\mathrm{B}_{1,}\right. & \left.\mathrm{A}_{1}\right) \\
> & \end{array}$ & $\left(\mathrm{B}_{1}, \mathrm{~A}_{2}\right)$ \\
\hline & $\begin{array}{l}\text { Perempuan } \\
\left(\mathrm{B}_{2}\right)\end{array}$ & $\begin{array}{ll}\left(\mathrm{B}_{2,}\right. & \left.\mathrm{A}_{1}\right) \\
> & \end{array}$ & $\left(\mathrm{B}_{2}, \mathrm{~A}_{2}\right)$ \\
\hline & & $\begin{array}{l}\left(\mathrm{B}_{1}, \mathrm{~A}_{1}\right)^{+} \\
\left(\mathrm{B}_{2}, \mathrm{~A}_{1}\right)>\end{array}$ & $\begin{array}{l}\left(B_{1}, A_{2}\right)+\left(B_{2}\right. \\
\left.A_{2}\right)\end{array}$ \\
\hline
\end{tabular}

Instrumen yang digunakan pada penelitian ini yaitu lembar tes hasil belajar. Data dalam penelitian ini 
diperoleh dengan menggunakan insrtumen tes hasil belajar.

Suatu tes sudah dikatakan layak digunakan atau belum, maka ada beberapa hal yang perlu dianalisa dari soal-soal tersebut meliputi :
a. Validitas Item Tes Hasil Belajar
b. Daya Pembeda.
c. Indeks Kesukaran Tes
d. Reliabilitas soal

Tes akhir diberikan pada kedua kelas sampel untuk menentukan hasil belajar Matematika peserta didik. Data yang diperoleh diuji dengan menggunakan uji analisis variansi dua arah dengan langkah-langkah sebagai berikut:
a. Uji Normalitas
b. Uji Homogenitas Variansi
c. Uji Hipotesis

\section{Hasil Penelitian dan Pembahasan Deskripsi data Pemahaman Belajar Siswa Kelas Sampel}

Data hasil belajar peserta didik dari kedua kelas sampel diperoleh setelah tes akhir hasil belajar Matematika yang terdiri dari pemahaman belajar Matematika

\section{Uji Persayaratan Analisis}

\section{Analisis Hasil Belajar Peserta Didik Kelas Sampel \\ a. Uji Normalitas Data}

Uji normalitas bertujuan untuk melihat data hasil belajar kedua kelas sampel berdistribusi normal atau tidak. Untuk melakukan uji normalitas digunakan uji Lilliefors. Setelah dilakukan perhitungan data pada kedua kelas sampel, maka diperoleh harga $L_{0}$ dan $L_{(n, \alpha)}$ dengan taraf nyata 0,05 .

Tabel 2.Hasil Uji Normalitas Data dari Tes Hasil Belajar Peserta Didik

\begin{tabular}{|c|c|c|c|c|c|}
\hline Kelas Sampel & $\mathbf{N}$ & $\boldsymbol{L}_{\mathbf{0}}$ & $\boldsymbol{L}_{\boldsymbol{t}}$ & Kesimpulan & Distribusi Data \\
\hline Eksperimen & 26 & 0,068 & 0,17 & $L_{0}<L_{\text {tabel }}$ & Normal \\
\hline Kontrol & 27 & 0,09 & 0,16 & $L_{0}<L_{\text {tabel }}$ & Normal \\
\hline
\end{tabular}

Tabel 3.Hasil Uji Normalitas Data dari Tes Hasil Belajar Peserta Didik Kelas Eksperimen Berdasarkan Jenis Kelamin

\begin{tabular}{|c|c|c|c|c|c|}
\hline Kelas Eksperimen & $\mathbf{N}$ & $\boldsymbol{L}_{\mathbf{0}}$ & $\boldsymbol{L}_{\boldsymbol{t}}$ & Kesimpulan & Distribusi Data \\
\hline Laki-laki & 14 & 0,226 & 0,227 & $L_{0}<L_{\text {tabel }}$ & Normal \\
\hline
\end{tabular}




\begin{tabular}{|l|c|c|c|c|c|}
\hline Perempuan & 12 & 0,1186 & 0,242 & $L_{0}<L_{\text {tabel }}$ & Normal \\
\hline
\end{tabular}

Untuk $\mathrm{F}(\alpha=0,05)(14,12)=2,64$

\section{Pengujian Hipotesis}

\section{b. Uji Homogenitas Variansi}

Uji homogenitas variansi bertujuan untuk melihat data hasil tes belajar kelas eksperimen dan kelas kontrol mempunyai variansi yang homogen atau tidak. Dalam uji homogenitas digunakan uji $\mathrm{F}$.

Perhitungan data dari kedua kelas sampel yakni kelas eksperimen dan kelas kontrol adalah sebagai berikut:

$$
\begin{gathered}
\mathrm{F}=\frac{\text { Varians terbesar }}{\text { Varians terkecil }}=\frac{166,541}{100,9} \\
=1,65
\end{gathered}
$$

Untuk F( $\alpha=0,05)(27,26)=1,90$

Perhitungan data dari kelas eksperimen berdasarkan jenis kelamin untuk kelompok laki-laki dan kelompok perempuan adalah sebagai berikut:

$$
\begin{gathered}
\mathrm{F}=\frac{\text { Varians terbesar }}{\text { Varians terkecil }}=\frac{237,6044}{189,1818} \\
=1,25
\end{gathered}
$$

Pengujian hipotesis dilakukan analisis varians dua arah. Analisis ini dapat dilakukan jika asumsi yang diperlukan terpenuhi. Riduwan (2013) menjelaskan bahwa sebelum melakukan pengujian harus dipenuhi persyaratan analisis terlebih dahulu dengan asumsi (1) data normal, artinya data yang dihubungkan berdistribusi normal, maka dilakukan uji normalitas dan (2) homogen, artinya data yang dibandingkan sejenis, maka perlu uji homogenitas. Dari hasil analisis tersebut dapat disimpulkan bahwa variabel hasil belajar adalah normal dan mempunyai varians yang homogen.

Setelah dilakukan analisis varians dua arah, maka dapat dibuat ringkasan analisis dua arah seperti Tabel berikut.

Tabel. Hasil Perhitungan Anava Dua Arah

\begin{tabular}{|c|c|c|c|c|c|}
\hline Sumber Variansi & JK & db & KR & F Hitung & F Tabel \\
\cline { 1 - 5 } Antar (A) & 87,76 & 1 & 87,761 & 0,64 & \\
\cline { 1 - 5 } Antar (B) & 1,04 & 1 & 1,04 & 0,007 & \multirow{2}{*}{4,04} \\
\cline { 1 - 4 } Antar (AB) & 33,20 & 1 & 33,20 & 0,24 & \\
\cline { 1 - 5 } Dalam Residu & 6636,1 & 49 & 135,43 & & \\
\hline Total & 6758,1 & 52 & - & & \\
\hline
\end{tabular}


Berdasarkan hasil analisis tersebut selanjutnya dilakukan pengujian hipotesis.

\section{Pengujian Hipotesis 1}

Hipotesis pertama yang diajukan adalah sebagai berikut:

Hasil analisis perhitungan diperoleh nilai $\mathrm{F}$ Hitung $=0,64$ dan $\mathrm{F}$ Tabel $=4,04$. Dengan taraf signifikansi $5 \% \quad$ maka $F_{\text {hitung }}<F_{(\alpha, d k)}, \quad$ berarti hipotesis $\mathrm{H}_{0}$ diterima dan hipotesis penelitian ditolak.Dapat disimpulkan bahwa tidak terdapat perbedaan pemahamanbelajar peserta didik yang diajar menggunakan Pendekatan CTL dengan pemahaman belajar peserta didik yang diajar menggunakan pendekatan konvensional di kelas IV SDN Kecamatan Padang Utara Kota Padang.

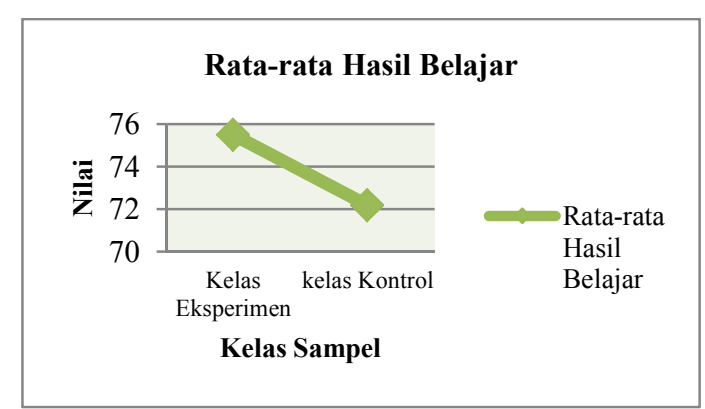

Gambar. Rata-rata hasil belajar kelas eksperimen dan kelas kontrol

\section{Pengujian Hipotesis 2}

Hipotesis kedua yang diajukan adalah hasil analisis perhitungan diperoleh nilai $\mathrm{F}$ Hitung $=0,07$ dan $\mathrm{F}$ Tabel $^{=} 4,04$. Dengan taraf signifikansi $5 \% \quad$ maka $F_{\text {hitung }}<F_{(\alpha, d k)}$, berarti hipotesis $\mathrm{H}_{0}$ diterima dan hipotesis penelitian ditolak.Berdasarkan perhitungan di atas $F_{\text {hitung }}<F_{(\alpha, d k)}$, berarti hipotesis $\mathrm{H}_{0}$ diterima.

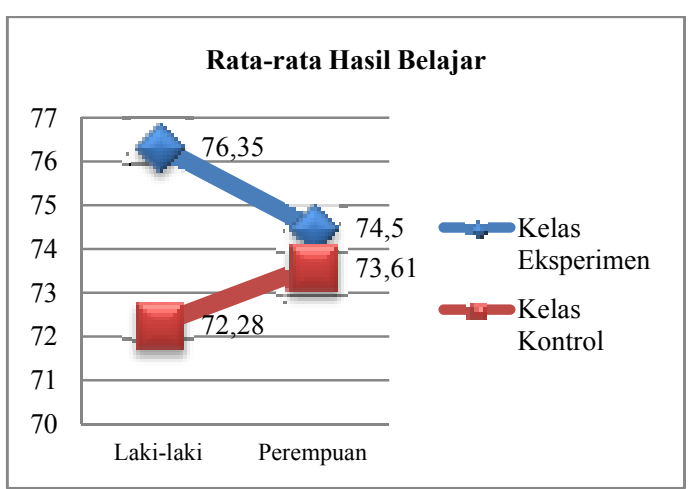

Gambar. Rata-rata hasil belajar kelas eksperimen dan kelas kontrol berdasarkan jenis kelamin

\section{Pengujian Hipotesis 3}

Hipotesis ketiga yang diajukan adalah sebagai berikut:

Hasil analisis perhitungan diperoleh nilai $\mathrm{F}$ Hitung $=0,24$ dan $\mathrm{F}$ Tabel $=4,04$. Dari hasil perhitungan diperoleh kesimpulan Antar grup (AB) $\mathrm{f}$ hitung $<\mathrm{f}_{\text {tabel }}$ maka terima $\mathrm{H}_{\mathrm{o}}$ artinya tidak terdapat interaksi yang signifikan antara pendekatan pembelajaran dengan jenis kelamin dalam mempengaruhi pemahamanMatematika peserta didik.

\section{Pembahasan}


Penelitian yang peneliti laksanakan adalah di kelas IV SDN 13 Lolong dan 11 Lolong Kota Padang. Berdasarkan hasil pengujian hipotesis dapat dijabarkan sebagai berikut:

1. Tidak Terdapat Perbedaan Pemahaman Belajar Peserta Didik yang Diajar Menggunakan Pendekatan CTL dengan Pemahaman Belajar Peserta Didik yang Diajar Menggunakan Pendekatan Konvensional di Kelas IV SDN Kota Padang Kecamatan Padang Utara.

Pengujian hipotesis pertama pada penelitian ini adalah melihat terdapat atau tidaknya perbedaan pemahaman belajar peserta didik yang diajar menggunakan pendekatan CTL dengan pemahaman belajar peserta didik yang diajar menggunakan pendekatan konvensional. Berdasarkan analisis data yang diperoleh, tidak terdapat perbedaan pemahaman belajar peserta didik yang diajar menggunakan pendekatan CTL dengan pemahaman belajar peserta didik yang diajar menggunakan pendekatan konvensional. Hal ini dapat dilihat pada tes akhir peserta didik yang diberikan kepada kelas eksperimen dan kelas kontrol.

2. Tidak Terdapat Perbedaan Pemahaman Belajar Peserta Didik yang Diajar Menggunakan Pendekatan CTL Berdasarkan Jenis
Kelamin di Kelas IV SDN Kota Padang Kecamatan Padang Utara.

Berdasarkan analisis data yang diperoleh, tidak terdapat perbedaan pemahaman belajar peserta didik yang diajar menggunakan pendekatan CTL dan Konvensional berdasarkan jenis kelamin. Hal ini dapat dilihat pada tes akhir peserta didik yang diberikan kepada kelas eksperimen.Pada proses pemebelajaran pada kelas eksperimen terlihat peserta didik laki-laki lebih aktif untuk bertanya dan tampil ke depan dibandingkan peserta didik perempuan.

Menurut kajian American Psychological Association (dalam Lestari, 2010) menjelaskan bahwa analisis terbaru dari penelitian internasional kemampuan perempuan di seluruh dunia dalam matematika tidak lebih buruk dari pada kemampuan lakilaki meskipun laki-laki memiliki kepercayaan diri yang lebih dari perempuan dalam matematika, dan perempuan-perempuan dari negara dimana kesamaan gender telah diakui menunjukkan kemampuan yang lebih baik dalam tes matematika.

Beberapa para ahli mengatakan bahwa kemampuan penguasaan matematika dan pemecahan masalahantara peserta didik laki-laki 
dan perempuan tidak berbeda dan merekamemiliki kemampuan yang sama dalam menyelesaikan matematika. Oleh karena itu, pada penelitian ini antara kelompok laki-laki dan perempuan tidak memiliki pemahaman Matematika yang berbeda.

3. Tidak Terdapat Interaksi Antara Pendekatan Pembelajaran dengan Jenis Kelamin Dalam Mempengaruhi Pemahaman Belajar Siswa Kelas IV SDN Kota Padang Kecamatan Padang Utara.

Pengujian hipotesis ketiga pada penelitian ini adalah melihat terdapat atau tidaknya interaksi antara pendekatan pembelajaran denganjenis kelamin dalam mempengaruhi pemahaman belajar siswa kelas IV SDN Kota Padang Kecamatan Padang Utara. Berdasarkan analisis data yang diperoleh, tidak terdapat interaksi antara pendekatan pembelajaran dengan jenis kelamin dalam mempengaruhi pemahaman belajar siswa kelas IV SDN Kota Padang Kecamatan Padang Utara. Hal ini dapat dilihat pada tes akhir peserta didik yang diberikan kepada peserta didik. Dengan tidak adanya interaksi ini menunjukkan bahwa, tanpa memperhatikan jenis kelamin peserta didik proses pembelajaran dengan menggunakan pendekatan CTL dan pendekatan konvensional dapat dilaksanakan. Hal ini menunjukkan bahwa pendekatan pembelajaran tidak bergantung pada jenis kelamin maupun mempengaruhi pemahaman belajar peserta didik.

\section{Penutup}

\section{Kesimpulan}

Berdasarkan hasil penelitian yang telah dikemukakan, maka dapat disimpulkan:

1. Tidak terdapat perbedaan pemahaman belajar peserta didik yang diajar menggunakan Pendekatan CTL dengan Pemahaman belajar peserta didik yang diajar menggunakan Pendekatan Konvensional di kelas IV SDN Kota Padang Kecamatan Padang Utara.

2. Tidak terdapat perbedaan pemahaman belajar peserta didik yang diajar menggunakan Pendekatan CTL berdasarkan jenis kelamin di kelas IV SDN Kota Padang Kecamatan Padang Utara.

3. Tidak terdapat interaksi antara pendekatan pembelajaran dengan jenis kelamin dalam mempengaruhi 
pemahaman belajar siswa kelas IV

SDN Kota Padang Kecamatan

Padang Utara

\section{Saran}

Berdasarkan kesimpulan di atas dapat dikemukakan beberapa saran untuk perbaikan hasil pembelajaran, antara lain:

1. Berdasarkan hasil penelitian ini terlihat bahwa dengan menggunakan rencana pembelajaran yang baik dapat membuat proses pembelajaran lebih terarah. Diharapkan kepada guru dalam merancang pembelajaran, agar memperhatikan indikator yang ingin dicapai agar proses pembelajaran berjalan dengan baik.

2. Memperhatikan bahwa tidak terdapat keterkaitan antara jenis kelamin dengan pendekatan yang digunakan, disarankan kepada guru agar tidak membeda-bedakan siswa laki-laki dengan siswa perempuan dalam memilih pendekatan mengajar karena semua pendekatan pembelajaran bagus tergantung dari kreativitas guru dalam melaksanakannya.

3. Dalam melihat pemahaman belajar siswa, diharapkan kepada guru untuk memperhatikan masing- masing tingkatan indikator pemahaman yang digunakan. Sehingga soal yang dirancang lebih baik dan dapat mengukur pemahaman masing-masing siswa.

4. Bagi kepala sekolah agar lebih memahami inovasi baru berbagai pendekatan pembelajaran sehingga dapat membimbing guru-guru dalam menggunakan Pendekatan pembelajaran dalam proses pembelajaran Matematika.

5. Bagi pengawas lebih memahami berbagai pembaharuan dibidang pendidikan sehingga dapat menambah wawasan dan pemahaman pengawas dalam membina dan membimbing para guru dalam merancang pembelajaran Matematika dengan menggunakan pendekatan pembelajaran.

6. Bagi peneliti lainnya yang berminat melanjutkan penelitian ini untuk memperhatikan kelemahan penelitian ini, sehingga penelitian yang dilakukan dapat menghasilkan sesuatu yang lebih sempurna. Penelitian ini peneliti lakukan dalam ruang lingkup yang terbatas baik dari segi materi maupun subjek penelitian. Oleh karena itu 
perlu diadakan penelitian lanjutan dengan lingkup yang lebih luas sehingga kesimpulan yang diambil berlaku lebih umum.

\section{Daftar Rujukan.}

Arikunto, Suharsimi. 2003. DasarDasar Evaluasi Pendidikan (Edisi Revisi). Jakarta: PT Bumi Aksara.

Depdiknas. 2001.Kurikulum Tingkat Satuan Pendidikan. Jakarta: Depdiknas

Lestari, N.D.F. 2010.Profil Pemecahan Masalah Matematika OpenEnded SiswaKelas V Sekolah Dasar Ditinjau dari Perbedaan Gender dan Kemampuan Matematika.Tesis. Surabaya: Unesa

Mukhlis. 2012. Model Pembelajaran CTL, (Online), (http://mukhliscaniago.wordpres s.com $/ 2012 / 02 / 24 /$ modelpembelajaran-ctl/, diakses pada tanggal 20 Desember 2015)

Muliyardi. 2002. "Pengembangan Model Pembelajaran Matematika Menggunakan Komik di Kelas I Sekolah Dasar". Disertasi tidak diterbitkan. Surabaya: Universitas Negeri Surabaya

Pemerintah RI. 2003. Undang-Undang Sistem Pendidikan Nasional No.22 tahun 2003. Jakarta: Depdiknas.

Riduwan. 2013. Dasar-dasar Statistika. Bandung : Alfabeta
Santrock, Jhon W. 2007. Perkembangan Anak, Edisi Ketujuh, Jilid Dua. Jakarta:Erlangga

Taufik, Taufina. 2012. Mozaik Pembelajaran Inovatif. Padang: Sukabina Press.

Trianto.2010. Mengembangkan Pembelajaran tematik. Jakarta: Kencana.

Uno, Hamzah., dan Koni, Satria. 2012. Assessment Pembelajaran. Jakarta: Bumi Aksara.

Upton, Penney. 2012. Psikologi Perkembangan. Jakarta:Erlangga

Wallace. 1992. Pendekatan Konservatif. Tersedia di www. Dunia pelajar.com > Pend. Matematika 
